\title{
Effects of food plots on white-tailed deer in Kisatchie National Forest
}

\author{
MARK K. JOHNSON AND KENNETH D. DANCAK
}

\begin{abstract}
The authors are professor, School of Forestry, Wildlife and Fisheries, Louisiana Agricultural Experiment Station, Louisiana State University Agricultural Center, LSU, Baton Rouge 70803; and wildlife biologist, Vernon Ranger District, Kisatchie National Forest, 3362 Lake Charles Hwy., Leesville, La 71446.
\end{abstract}

\begin{abstract}
An extensive food plot program maintained for 4 years on the National Red Dirt Wildlife Management Preserve of the Kisatchie National Forest, La., failed to produce improvements in southern pine-mixed hardwood forest range sufficient to affect quality of deer (Odocoileus virginianus) harvested by sport hunters. A combination of normal forest management practices plus maintenance of deer densities at relatively low levels was apparently sufficient for maintaining deer in good condition. Other than for public relations, the food plot program was not warranted based on biological effects.
\end{abstract}

Keywords: antler, deer, Kisatchie, Louisiana, National Forest, nutrition, Odocoileus virginianus

It is generally known that understory range in upland forests of the southeastern United States is low in forage quality from midsummer through winter. Even cows require seasonal supplementation with energy and protein sources to maintain high calving percentages and for growth of calves (Byrd 1980). Present use of National Forest range in the southeastern U.S. is dominated by wildlife habitat and recreational hunting. Concern for improving wildlife habitat and productivity of game species is growing in order to better comply with multiple-use objectives of National Forests which include use of the understory range resources.

Food plots used to supplement diets provided by understory range can contribute to increases in body and antler size of whitetailed deer (Odocoileus virginianus), especially in poor-quality habitat (Johnson et al. 1987, Keegan et at. 1989). However, previous demonstrations (Johnson et al. 1987, Keegan et al. 1989) have reported on upland pine-mixed hardwood range with high animal unit densities of both deer and cattle. National Forest lands in Louisiana comprise about 250,000 ha of upland pine-hardwood range available for public use. Cattle are excluded from most of the forest, and timber thinning plus prescribed burning practices are conducted regularly compared to overstocked, unthinned timber on private lands where deer responded to forage supplements (Johnson et al. 1987).

Decreased habitat due to conversion of lands to agricultural production (Newsom 1984) and an increased demand for hunting on private lands (Dudderar 1981) imply that the role of National Forests will increase in importance for the hunting public. Magazine articles tout positive aspects of food plots on deer, and sport hunters often request that these practices be used on public lands. However, there are no data available to assess whether this type of

\footnotetext{
Research funding was provided by the USDA Forest Service with Challenge Grant funds and by the Louisiana Agricultural Experiment Station under McIntire-Stennis Project LA 2154. R. Costa and F. Rothwein, both of the Forest Service, and A. Allen, Northwestern State University, Natchitoches, La., provided field assistance. B.D. Nelson provided assistance with forage analyses. Approved for publication by the Director of Louisiana Agricultural Experiment Station as Manuscript 91-22-5005. Manuscript accepted 7 June 1992.
}

range improvement is warranted. It is important to know the extent to which food plots might affect the deer resource in order to determine the feasibility of this practice. The purpose of the study was to determine whether food plots well distributed on a managed National Forest would increase body weights and antler development of white-tailed deer. Secondarily, biologists with the Kisatchie National Forest and Louisiana Department of Wildlife and Fisheries were interested in knowing whether food plots would help to increase the harvest rate of deer.

\section{Study Area}

The study area was the National Red Dirt Wildlife Management Preserve of the Kisatchie National Forest. The Preserve, located in southcentral Natchitoches Parish in west-central Louisiana, is a 15,516-ha subcomponent of the Kisatchie Ranger District in the Kisatchie National Forest. The area is characterized by gently rolling to steep hills interspersed with numerous ravines and streams. Kisatchie-Oula soils predominate the Preserve. These soils are suited poorly for cultivated crops and pastureland because of excessive slope, low fertility, and rock outcrops. Average ( \pm SE) soil fertility was $7.7 \pm 1.2 \mathrm{ppm}$ exchangeable phosphorus (Bray No. 2), $27.2 \pm 3.8 \mathrm{ppm}$ extractable potassium, $307.7 \pm 26.9 \mathrm{ppm}$ calcium, $47.2 \pm 5.4 \mathrm{ppm}$ magnesium, $1.3 \pm 0.1 \%$ organic matter, and a logarithmic pH average of $4.9(n=18)$ based on soil fertility tests conducted at Louisiana State University Agricultural Center's Soil Testing Laboratory.

Approximately $25 \%$ of the study area consists of bottomland vegetation (Chatham 1959). Bottomlands are highly dispersed and a wide variety of vegetation exists therein. The remainder is covered by upland vegetation. The flora is described by Dancak (1990). Timber harvesting has resulted in a habitat mosaic; clearcuts average $16-20$ ha for pine and 6-8 ha for hardwoods. Timber is thinned to $\approx 1.88$ to $3.76 \mathrm{~m}^{2} /$ ha basal area, dependent on timber type, age, and site index (C. Ernst, Other Resources Assistant, USDA Forest Service Kisatchie National Forest, pers. commun.).

\section{Methods}

\section{Selection of Treatment and Control Units}

Prior to initiation of this study, historical data and timber type maps were closely examined to select areas with habitat compositions which were similar. Treatment and control areas were selected to have similar amounts of pine, hardwood, and recent clearcuts. Deer body weights and kill location data for the 3 years prior to the study were used to verify that study unit selections were reasonably unbiased. We reasoned that areas producing similar sized deer with similar annual harvest rates were biologically similar with respect to our study needs. A priori data from harvested deer also provided pretreatment data allowing evaluation of results from the aspect of before and after treatment on the same areas. 
The entire Preserve, excluding the National Red Dirt Wilderness, which is located on the eastern periphery, was utilized in this study. Two treatment units 2,383 ha and 1,489 ha, and 2 control units, 2,525 ha and 2,484 ha, were incorporated into the experimental design. Treatment units were diagonally opposite as were control units. Food plots were established on treatment units; no food plots were established on control units. A nonfenced buffer zone separated the 4 study units to offset the potential problem of deer movement among areas. The buffer zone ranged from $\approx 1.2$ to $3.2 \mathrm{~km}$ in width. No food plots were established in the buffer and deer harvested from this area were excluded from statistical comparisons.

\section{Deer Inventory}

Strip censuses (Hayne 1949) of each study unit were made in 1987 and 1988. Six persons conducted a census on 4 consecutive days in August 1987 and 4 persons conducted a census on 4 consecutive days in August 1988. A total of 9 and 10 transects were surveyed in control units, and 9 and 10 transects were surveyed in treatment units in 1987, and a total of 8 transects were surveyed in each unit in 1988. Differences in effort between years resulted from a lack of available persons. Deer density on each study unit was estimated with the Hayne (1949) formula. Average deer density on the $\mathbf{4}$ study units was used to estimate the size of the deer population on the entire Preserve.

\section{Food Plot Establishment}

Eighteen plots of cool-season and 12 plots of warm-season forage were established in 1 treatment unit; 11 plots of cool-season forages and 6 plots of warm-season forage were established in the other treatment unit. Total area used for food plots in this study was based on findings that $\mathbf{0 . 4}$ ha of warm-season food plots and 0.4 ha of cool-season food plots significantly $(P<0.05)$ supplemented the diets of $\approx 20$ and 10 deer, respectively (Johnson et al. 1987, Keegan et al. 1989). R. Costa, Forest Service Wildlife Biologist, Kisatchie Ranger District, estimated the deer population to be $1 \mathrm{deer} / 10$ ha at the onset of the study. Consequently, we grew enough cool- and warm-season forages to supplement $1 \mathrm{deer} / \mathrm{ha}$.

Warm-season plots were either adjacent to or within $250 \mathrm{~m}$ of cool-season plots. No plot was closer than $0.1 \mathrm{~km}$ from the buffer zone and the nearest distance between any 2 plots was $0.3 \mathrm{~km}$. Average ( $\pm \mathrm{SE}$ ) distance between any 2 plots was $0.6 \pm 0.3 \mathrm{~km}$. Distribution of food plots was roughly uniform in both treatment units and similar to that on Blairstown, where nearly $100 \%$ of deer used food plots (Johnson et al. 1987). Cool-season food plots were $0.58 \pm 0.05$ ha and warm-season food plots were $0.44 \pm 0.03$ ha in average size.

Warm-season plots were planted exclusively with American jointvetch (Aeschynomene americana L.) in June 1986; half of each cool-season plot was planted with Kenland red clover ( Trifolium pratense L.) plus Caldwell wheat (Triticum aestivum L.) and half with Mt. Barker subterranean clover ( $T$. subterraneum L.) plus Caldwell wheat in October 1986. Jointvetch provided forage from $\approx$ April until November; cool-season forages provided forage from $\approx$ April until November; cool-season forages provided forage from $\approx$ October to June.

All food plots received $2,242 \mathrm{~kg}$ / ha of ground agricultural limestone and $224 \mathrm{~kg} / \mathrm{ha}$ of 8-24-24 fertilizer (8 kg nitrogen, $24 \mathrm{~kg} \mathrm{P} \mathbf{P}_{2} \mathrm{O}_{5}$ and $24 \mathrm{~kg} \mathrm{~K} \mathrm{~K}_{2} 0$ per $100 \mathrm{~kg}$ ) prior to the first growing season. Warm-season plots received an additional $11 \mathrm{~kg} / \mathrm{ha}$ of borax fertilizer. The following 3 years, $224 \mathrm{~kg} /$ ha of 8-24-24 fertilizer was applied in September to each cool-season food plot, and in May to each warm-season food plot. Plots were disked $\approx 15 \mathrm{~cm}$ deep to disseminate the fertilizer and lime and to provide a well-prepared seedbed. Seeding rates were $17 \mathrm{~kg} / \mathrm{ha}$ jointvetch, $6 \mathrm{~kg} / \mathrm{ha}$ red clover, $10 \mathrm{~kg} / \mathrm{ha}$ subclover, and $100 \mathrm{~kg} / \mathrm{ha}$ wheat. Seeds were harrowed into the soil to promote seed-soil contact.

\section{Deer Use of Food Plots}

Deer exclosures were placed randomly on 10 randomly selected jointvetch plots ( 5 in each treatment unit). Exclosures on jointvetch plots were constructed of hogwire $\left(\approx 100 \mathrm{~cm}^{2}\right.$ mesh) with steel rods used for vertical support. These exclosures covered a ground area of $\approx 1 \mathrm{~m}^{2}$ and were $\approx 1.8 \mathrm{~m}$ tall to prevent deer from browsing the tall-growing jointvetch or from reaching in for lower growing forages. Exclosures were placed on 20 randomly selected cool-season plots. Ten of the 20 cool-season plot exclosures were situated randomly in red clover and the remaining 10 exclosures were placed randomly in subclover. Exclosures in clover also were constructed of hogwire and covered a ground area of $\approx 1 \mathrm{~m}^{2}$. All exclosures were lined at the bottom with $0.6 \mathrm{~cm}$ mesh hardward cloth to prevent grazing by rabbits ( $S y$ lvilagus $\mathrm{spp}$ ). We sampled only 10 plots of each type simply to provide an estimate of mean production. We expected large variation in yields among plots due to differences in soils and scattered precipitation. More intensive sampling was not required because we were not interested in statistically comparing yields between individual plots or plot types. The large number of clippings needed for this purpose may have affected total yields available to deer. We decided to use only 1 exclosure per plot to minimize this potential study effect.

To estimate forage production and deer use, vegetative clippings in the center of exclosures and immediately outside exclosures in randomly selected positions were collected in June, August, and October from 1986 to 1987 for jointvetch and January, March, and May from 1987 to 1988 for clovers and wheat. A clipping frame with $400-\mathrm{cm}^{2}$ aperture was used to standardize the amount of clipped vegetation. Forages were clipped $\approx 1 \mathrm{~cm}$ above ground level, and after each clipping, each exclosure was randomly replaced on the same plot. Clippings were oven-dried at $60^{\circ} \mathrm{C}$ for 48 hours and weighed to the nearest $0.01 \mathrm{~g}$. Deer use was estimated by subtracting vegetative yield within exclosures from that obtained outside of exclosures.

Thirty fecal pellet groups in each study unit were collected in August, January, and May from 1986 to 1988. Pellet collection extended through 2 complete warm-season and cool-season forage growth cycles. Pellet groups were placed in separate air-tight plastic bags, and after the complete seasonal quota of fecal pellets had been collected, they were oven-dried at $60^{\circ} \mathrm{C}$ for 48 hours and and ground in a Wiley mill through a 40 -mesh screen. Dietary crude protein and fecal nitrogen are significantly associated in ruminants (Mould and Robbins 1981). All fecal samples were analyzed to determine crude protein content in order to provide a gross indicator as to differences in dietary quality. Johnson et al. (1987) found significant differences in fecal crude protein in similar habitat in relation to presence or absence of food plots planted with similar forages. Fecal samples were analyzed microhistologically for presence or absence of food plot forages (Johnson et al. 1987) to assess whether deer were moving among treatment and control units.

\section{Data from Harvested Deer}

A deer check station at the Preserve was staffed by Kisatchie National Forest, Northwestern State University, and LSU School of Forestry, Wildlife, and Fisheries personnel during the gunhunting portion of the deer seasons. Data were collected for 3 years prior to establishing food plots and for 4 years following establishment of the food plots. Pretreatment data was used to aid in selection of study areas and for baseline assessment of deer condition. Forage production and deer use of food plots was estimated for 2 years to ensure that deer were using the food plots. The food plots were maintained for 4 years and data on harvested deer were collected to ensure adequate sample size for analysis and to minimize any effects due to year of study that might confound our results. 
Table 1. Mean ( \pm SE) food plot production (kg/ha) and deer use at National Red Dirt Wildlife Munagement Preserve, Louisiana; $1986-1988$ (n = 30 for jointvetch, red clover, and subclover; $n=60$ for wheat).

\begin{tabular}{|c|c|c|c|c|c|}
\hline Period & Forage type & Production & Deer use & Use & Forage consumption \\
\hline & & $\mathrm{kg} / \mathrm{ha}$ & $\mathrm{kg} / \mathrm{ha}$ & $\%$ & $\mathrm{~kg} /$ deer/day \\
\hline Jun 86-Nov 86 & Jointvetch & $1813 \pm 473$ & $559 \pm 64$ & 20 & 0.34 \\
\hline Oct $86-$ May 87 & Cool-Season ${ }^{b}$ & $2373 \pm 664$ & $352 \pm 60$ & 15 & 0.38 \\
\hline Apr 87-Oct 87 & Jointvetch & $3025 \pm 783$ & $750 \pm 26$ & 16 & 0.39 \\
\hline Oct $87-$ May 88 & Cool-Season ${ }^{c}$ & $1316 \pm 362$ & $350 \pm 34$ & 11 & 0.43 \\
\hline Apr $88-N o v 88$ & Jointvetch & $338 \pm 60$ & $116 \pm 16$ & 34 & 0.7 \\
\hline
\end{tabular}

${ }^{a}$ Estimate of $\mathrm{kg}$ of food plot forages consumed/deer/day based on estimate of 1 deer/36.0 ha in 1987 and 1 deer/43.3 ha in 1986 and 1988

${ }^{b}$ Red clover, subclover, and wheat.

${ }^{c}$ Red clover and subclover.

Only results for yearling deer are shown here because this age class produced the largest sample size for statistical comparisons. Older deer were much fewer in the harvest and were often produced prior to the study. Hunters were required to check in and out of the station each day, bring killed deer to the station before fielddressing, and report kill location by locating their hunting area on a large map of the Preserve. The check station was located near the center of the 4 study units. Technicians observed the direction from which each vehicle came to aid the accurate identification of hunting locations. Killed deer were weighed to the nearest pound with a Jacobs Detecto balance scale (New York, N.Y.) and age was estimated by tooth wear and eruption (Severinghaus 1949). Humerus length (distance from proximal tip of the greater tuberosity to the distal tip of the lateral epicondyle) was used as an additional index of body size. Antler points $(\geq 2.5 \mathrm{~cm}$ ) were counted and antler measurements (Dancak 1990) on each male with antlers were added for an antler score. Total antler score was comprised of the number of points $(\geq 1 \mathrm{~cm}$ ), the sum of all main beam and antler point lengths, plus the widest point of outside antler spread.

\section{Statistical Analyses}

Differences between treatment and control units in mean numbers of deer seen $/ \mathrm{km}$ of transect were analyzed with Chisquare goodness-of-fit test. Differences between treatment and control units in deer body weights, humerus lengths, antler points, antler scores, and fecal crude proteins were compared with Student's $t$ tests. Data presented here are means \pm standard errors.

\section{Results}

\section{Deer Inventory}

In 1987, the deer herd on the Preserve was estimated to be $427 \pm$ 162 deer, which is equivalent to 1 deer/36.4 \pm 13.8 ha. No significant difference $(P>0.90)$ was found in estimated deer densities among the study units in 1987 . The estimated deer population during 1988 was $356 \pm 72$ deer, ( 1 deer $/ 43.7 \pm 8.8$ ha). No significant difference $(P>0.80)$ in deer density existed among study units in 1988. Deer densities on the Preserve were much lower than those on private land ( 1 deer/10.4 ha) where food plots significantly improved deer growth (Johnson et al. 1987). We are reasonably confident in our estimates of deer densities because they were within $10 \%$ of that reported by Aycock (1968) who estimated deer population size on the Preserve with a Lincoln Index procedure. Hunter success then (1 deer/17 efforts) was similar to the success rate during our study (1 deer/19 efforts). During the whole study period, the grand average hunter success rate was $20.2 \pm 4.0$ efforts and $17.4 \pm 2.7$ efforts per legally harvested deer from food plot versus control units, respectively.

\section{Food Plot Production and Deer Use}

Annual production of jointvetch averaged $1,725 \pm 777 \mathrm{~kg} / \mathrm{ha}$ from 1986 to 1988 (Table 1). Deer use of jointvetch averaged $23 \pm$ $5 \%$ of the available forage. Jointvetch provided an average of 0.27 kg of oven-dry forage/deer/day on food plot units. Annual production of cool-season forage averaged $1,270 \pm 310 \mathrm{~kg} / \mathrm{ha}$ (subclover), $1,326 \pm 104 \mathrm{~kg} / \mathrm{ha}$ (red clover), and $643 \pm 196 \mathrm{~kg} / \mathrm{ha}$ (wheat). Cool-season forages provided an average of $0.40 \mathrm{~kg}$ of oven-dry forage/deer/day. These estimates are only slightly lower than those reported for private land where food plots apparently increased sizes of deer and similar estimates of plot use were associated with about $35 \%$ to $40 \%$ of deer diets (Johnson et al. 1987).

\section{Fecal Pellet Results}

Fecal crude protein averaged $17.3 \pm 1.2 \%$ on control units and $17.0 \pm 1.3 \%$ on food plot units from August 1986 to May 1988 (Table 2). No significant difference $(P \geq 0.10)$ in fecal crude protein

Table 2. Crude protein content (\%) of deer samples collected on control and food plot units at National Red Dirt Wildlife Management Preserve, Louisiana; 1986-1988 ( $n=60$ samples/treatment/collection period).

\begin{tabular}{lccc}
\hline \hline Sample period & Control Units & Food Plot Units & P \\
\hline \hline & $\%$ & $\%$ & \\
Aug 86 & $17.3 \pm 0.4$ & $16.9 \pm 0.3$ & 0.39 \\
Jan 87 & $14.6 \pm 0.4$ & $13.4 \pm 0.3$ & 0.02 \\
May 87 & $20.9 \pm 0.4$ & $21.0 \pm 0.4$ & 0.85 \\
Aug 87 & $17.7 \pm 0.5$ & $17.3 \pm 0.3$ & 0.55 \\
Jan 88 & $13.5 \pm 0.3$ & $13.4 \pm 0.2$ & 0.77 \\
May 88 & $19.7 \pm 0.4$ & $19.7 \pm 0.3$ & 0.94 \\
\hline
\end{tabular}

existed between samples collected on treatment versus control units. However, fecal pellets contained significantly $(P<0.01)$ more crude protein in spring samples compared to winter samples for both treatment and control areas. This finding supports the idea that the method was adequate for detecting gross differences in dietary crude protein that might have occurred between the areas.

We do not believe that the study was confounded by deer movements among areas. No food plot forages were found in fecal pellets collected from control units during the study. Conversely, most fecal samples collected on food plot units contained food plot forages: August 1986, 84\%; January 1987, 58\%; May 1987, 82\%; August 1987,90\%; January 1988,83\%; and May 1988, 90\%. Lower apparent use of plots was recorded in January because growth of the forages was least during the coldest part of winter.

\section{Body Weights of Deer and Antler Measurements}

Mean body weights (whole) of 1.5-year-old males averaged 46.9 $\pm 1.2 \mathrm{~kg}$ on control units and $47.6 \pm 1.8 \mathrm{~kg}$ on food plot units from 1986 to 1989 (Table 3). Mean body weights (whole) of 1.5-year-old females averaged $39.0 \pm 1.6 \mathrm{~kg}$ on control units and $40.3 \pm 0.7 \mathrm{~kg}$ on food plot units during the same period. No significant differences $(P \geq 0.13)$ were observed in body weights of males or females from control versus food plot units. Mean humerus lengths of 1.5-year-old males averaged $26.2 \pm 0.1 \mathrm{~cm}$ on control units and 
Table 3. Pretreatment and post-treatment mean ( \pm SE) body welghts $(\mathrm{kg})$ of 1.5-yr-old male and female deer harvested on control and food plot units at National Red Dirt Wildlife Management Preserve, Louisiana; 1983-1989.

\begin{tabular}{|c|c|c|c|c|c|}
\hline Year & Control units & $\mathbf{n}$ & Food plot units & $\mathbf{n}$ & $\mathbf{P}$ \\
\hline \multicolumn{6}{|c|}{ Pretreatment Males: } \\
\hline 1983 & $50.0 \pm 1.7$ & 9 & $54.9 \pm 2.2$ & 6 & 0.10 \\
\hline 1984 & $47.7 \pm 1.6$ & 7 & $49.8 \pm 2.2$ & 8 & 0.45 \\
\hline 1985 & $47.5 \pm 1.8$ & 11 & $47.4 \pm 1.5$ & 17 & 0.96 \\
\hline \multicolumn{6}{|c|}{ Post-treatment Males: } \\
\hline 1986 & $47.8 \pm 1.2$ & 18 & $47.6 \pm 1.2$ & 26 & 0.91 \\
\hline 1987 & $49.1 \pm 1.5$ & 20 & $51.4 \pm 1.0$ & 14 & 0.27 \\
\hline 1988 & $47.0 \pm 1.0$ & 20 & $48.4 \pm 1.2$ & 22 & 0.39 \\
\hline 1989 & $43.7 \pm 0.6$ & 17 & $42.8 \pm 1.0$ & 11 & 0.40 \\
\hline \multicolumn{6}{|c|}{ Pretreatment Females: } \\
\hline 1983 & $40.9 \pm 3.5$ & 3 & $42.0 \pm 3.7$ & 2 & 0.87 \\
\hline 1984 & 42.7 & 1 & $39.3 \pm 3.4$ & 2 & 0.67 \\
\hline 1985 & 39.5 & 1 & $42.3 \pm 2.7$ & 4 & 0.69 \\
\hline \multicolumn{6}{|c|}{ Post-treatment Females: } \\
\hline 1986 & $39.5 \pm 1.2$ & 3 & $41.8 \pm 1.4$ & 5 & 0.31 \\
\hline 1987 & $43.4 \pm 1.6$ & 9 & $39.8 \pm 2.1$ & 4 & 0.22 \\
\hline 1988 & $37.5 \pm 2.9$ & 4 & 40.9 & 1 & 0.64 \\
\hline 1989 & $35.8 \pm 0.7$ & 7 & $38.6 \pm 2.3$ & 2 & 0.13 \\
\hline
\end{tabular}

$26.4 \pm 0.4 \mathrm{~cm}$ on food plot units from 1986 to 1989 . Mean humerus lengths of 1.5-year-old females averaged $24.6 \pm 0.5 \mathrm{~cm}$ on control units and $25.1 \pm 0.7 \mathrm{~cm}$ on food plot units during the same period. No significant differences ( $P \geq 0.20$ ) were observed in humerus lengths of males and females from control and food plot units. Mean number of antler points of 1.5-year-old males averaged 3.7 \pm 0.2 on control units and $3.6 \pm 0.2$ on food plot units from 1986 to 1989. No significant differences $(P \geq 0.13)$ in antler points were observed during this period. Similarly, mean antler scores of 1.5 year-old males on control units averaged $81.1 \pm 3.5$ and $81.5 \pm 2.0$ on food plot units from 1986 to 1989 . No significant differences $(P \geq 0.12)$ in antler scores were observed during this period. Similar results were obtained from fawns and older deer of both sexes (Dancak 1990).

\section{Cost}

Establishment cost of food plots considering seed, fertilizer, and labor was $\$ 566 /$ ha and about $\$ 134 / \mathrm{ha} / \mathrm{yr}$ for maintenance. The grand average expenditure was $\$ 87 / \mathrm{deer} / \mathrm{yr}$ using our population estimates.

\section{Discussion}

It was not our purpose to closely examine ecological or physiological relationships between deer and nutritional resources. The parameters we measured were specifically to ensure that the food plots had been significantly used by deer and that natural deer movement did not confound the study.

Because we detected no differences in body parameters and fecal crude protein was similar among control and food plot areas, we conclude that diet quality was not significantly improved by the food plots. Johnson et al. (1987) conducted the only published study providing evidence that food plots actually benefitted deer (Blairstown study area). Contrasting major differences between these study areas may provide important insights for future studies. Both the National Red Dirt Wildlife Management Preserve and Blairstown are comprised of planted and volunteer pine and mixed pine-hardwood forests. Both areas are predominated by infertile sandy and silt loam soils which are erodible. However, Blairstown has higher deer densities, greatly overstocked timber and the deer share their habitat with 150 cows. Assuming 1 cow eats as much forage as 5 deer, this represents 750 deer units plus about 100 actual deer. This herbivore density is about 1 deer unit per ha compared to about 1 per $\mathbf{4 0}$ ha for the Preserve. Obviously, the 2 areas represent gross extremes in habitat management with the Preserve being superior to Blairstown with respect to natural habitat for deer.

In addition to finding no apparent short-term biological effects of food plots on the deer, we also found no effects on hunter success. Our data should not be interpreted as suggesting that the food plots failed to attract deer. The large numbers of hunters who invade public areas simultaneously for short seasons probably affect deer movements and temporal feeding patterns differently than deer are affected on private land with less disturbance.

\section{Summary and Management Implications}

The high cost of the food plot program was not justified biologically in that deer did not increase in body size or antler development. In addition, neither population estimates nor hunter success suggested any differences in deer productivity between treatment and control areas. If deer density had been higher and native forages less available, the effects of food plots on deer growth might have been different.

Based on the results of this study, food plots in the Kisatchie National Forest can not be recommended for a deer management program. A small number of food plots could be installed to appease segments of the public who demand visual evidence of management activity, but the expense and lack of effects on deer do not support use of funds for supplemental feeding of deer at present ecological densities in the Kisatchie National Forest.

Seeds for deer food plots are being vigorously marketed commercially through sports magazines and hunters are questioning public agencies regarding plantings and their potential effects. Hunters often expect and imagine dramatic short-term effects of management. There have been little practical data available to wildlife biologists upon which to base management decisions or discussions with the public regarding food plots. The results of this study should be of interest to a wide audience of professionals responsible for management of public lands. Our results support the contention that when deer are biologically healthy and populations are well within carrying capacities of the range, expensive food plot programs are not likely to have dramatic effects. Furthermore, because the positive results of the Johnson et al. (1987) study were not large, it is not likely that the public would perceive any effects that might occur in some areas.

\section{Literature Cited}

Aycock, S.R., Jr. 1968. Population dynamics of the white-tailed deer herd on the Red Dirt Wildlife Management Area. M.S. Thesis. Louisiana State Univ., Baton Rouge.

Byrd, N.A. 1980. Forestland grazing a guide for service foresters in the south. Forest Rep. SA-FR10. USDA Forest Serv. Southeastern area. Atlanta, $\mathrm{Ga}$.

Chatham, T.W.1959. A study of an overpopulation of deer on the Red Dirt Game Management Area, Natchitoches Parish, Louisiana. M.S. Thesis. Louisiana State Univ., Baton Rouge.

Dancak, K.D. 1990. Effects of food plots on selected growth parameters, productivity, and harvesting of white-tailed deer in a National Forest. Ph.D. Diss. Louisiana State Univ., Baton Rouge.

Dudderar, G.R. 1981. Estimates of fee and lease hunting enterprises by state wildlife extension specialists. Proc. Third Ext. Wildl. and Fish. Workshop. Nov. 10-12. Baton Rouge, La. Coop. Ext. Serv. (Unpaginated proceedings).

Hayne, D.W. 1949. An examination of the strip census method for estimating animal populations. J. Wildl. Manage. 13:145-157.

Johnson, M.K., B.W. DeLany, S.P. Lynch, J.A. Zeno, S.R. Schultz, T.W. Keegan, and B.D. Nelson. 1987. Effects of cool-season agronomic forages on white-tailed deer. Wildl. Soc. Bull. 15:330-339. 
Keegan, T.W., M.K. Johnson, and B.D. Nelson. 1989. American jointvetch improves summer range for white-tailed deer. J. Range Manage. 42:128-134.

Mould, E.D., and C.T. Robbins. 1981. Nitrogen metabolism in elk. J. Wildl. Manage. 45:323-334.
Newsom, J.D. 1984. Coastal plain. p. 367-380. In: L.K. Halls (ed.), Whitetailed deer ecology and management. Stackpole Books, Harrisburg, Pa. Severinghaus, C.W. 1949. Tooth development and wear as criteria of age in white-tailed deer. J. Wildl. Manage. 13:195-216. 